\title{
Productive Efficiency in 16 European Countries
}

\author{
Dino Martellato \\ Università Ca' Foscari Venezia \\ Miguel A. Tarancón \\ Universidad de Castilla - La Mancha
}

\begin{abstract}
We investigate in this paper differences in productive efficiency across sixteen European countries. In order to assess differences in productive efficiency, we have built a dynamic input-output model and computed for each country the balanced growth rate and the balanced output composition. After that, we investigate how the differences existing between the output composition for balanced growth and the actual one relate to the differences between the rate of balanced growth and the actual one. In the final part of the paper we examine the influence of individual sectors on the rate of balanced growth by looking for growth-sensitive sectors.
\end{abstract}

Keywords Productive efficiency, input-output, growth, Europe.

JEL Codes C67, O47, P51.

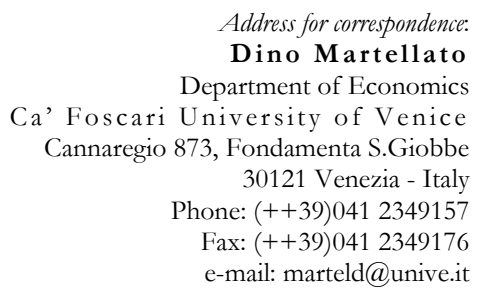

This Working Paper is published under the auspices of the Department of Economics of the Ca' Foscari University of Venice. Opinions expressed herein are those of the authors and not those of the Department. The Working Paper series is designed to divulge preliminary or incomplete work, circulated to favour discussion and comments. Citation of this paper should consider its provisional character.

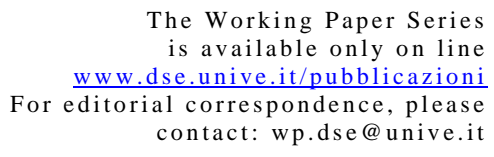

The Working Paper Series
Department of Economics Ca'Foscari University of Venice Cannaregio 873, Fondamenta San Giobbe 30121 Venice Italy

Fax: ++390412349210 



\title{
Productive Efficiency in 16 European Countries
}

\author{
Dino Martellato \\ Università Ca' Foscari Venezia \\ Miguel A. Tarancón \\ Universidad de Castilla - La Mancha
}

\begin{abstract}
We investigate in this paper differences in productive efficiency across sixteen European countries. In order to assess differences in productive efficiency, we have built a dynamic input-output model and computed for each country the balanced growth rate and the balanced output composition. After that, we investigate how the differences existing between the output composition for balanced growth and the actual one relate to the differences between the rate of balanced growth and the actual one. In the final part of the paper we examine the influence of individual sectors on the rate of balanced growth by looking for growth-sensitive sectors.
\end{abstract}

Keywords Productive efficiency, input-output, growth, Europe.

JEL Codes C67, O47, P51.

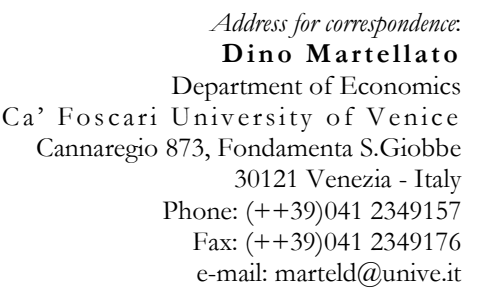

This Working Paper is published under the auspices of the Department of Economics of the Ca' Foscari University of Venice. Opinions expressed herein are those of the authors and not those of the Department. The Working Paper series is designed to divulge preliminary or incomplete work, circulated to favour discussion and comments. Citation of this paper should consider its provisional character.

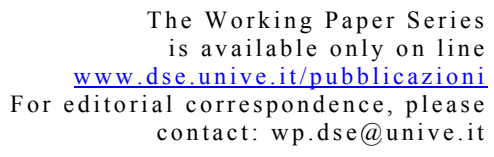

The Working Paper Series contact:wp.dse@unive.it
Department of Economics Ca'Foscari University of Venice Cannaregio 873, Fondamenta San Giobbe 30121 Venice Italy

Fax: ++390412349210 


\section{Introduction}

By utilizing the EUROSTAT input-output data base, and Italian data on the service life of capital assets, we investigate in this paper differences in productive efficiency across sixteen European countries. As productive efficiency bears upon total factor productivity, and thus on aggregate growth, in order to assess aggregate efficiency one would be tempted to simply compare real growth rates and then conclude that in economies where real growth is higher efficiency must be proportionately higher. This would be missleading, however, as productive efficiency in the aggregate economy actually reflects levels of efficiency in a range of different sectors, and also the output composition of the economy. So, in order to assess differences in productive efficiency, one has to distinguish firstly differences between countries in output composition and then differences within countries in respect of individual sectors.

As there is no common ideal output composition available, to isolate true differences in productive efficiency one has to find an alternative. A first possibility could consist of combining the matrix of the domestic multipliers of one country with the final demand of the remaining countries in the sample.

The solution adopted in this paper consists of building a dynamic inputoutput model and computing for each country the balanced growth rate and the balanced output composition. On this base, the actual growth rate in each country can be decomposed in two parts. The first is the balanced growth rate itself and the other is the difference between the two rates stemming from the distance separating the actual output composition from the one implying balanced growth. After briefly discussing the structure of the dynamic model and its results, we investigate how the differences existing between the output composition for balanced growth and the actual one relate to the differences between the rate of balanced growth and the 
actual one. In the final part of the paper we examine the influence of individual sectors on the rate of balanced growth by looking for growthsensitive sectors i.e. whether there are some sectors which have a proportionately bigger influence and whether there are sectors where a reduction in the intermediate and capital input coefficients has relatively greater effect.

\section{Productive Efficiency}

One way of defining productive efficiency in a sector is by utilising the familiar concept of "production possibility frontier" i.e. the maximal amount of output that can be obtained with the available resources. According to Ten Raa, the degree by which the actual level of output is lower than the maximal one possible measures the inefficiency in that sector, from which it follows that efficiency is synonymous with proximity to that frontier (Ten Raa, 2005). An alternative way of measuring efficiency considers "total factor productivity" (Wolff, 1985). Utilising an Input-Output framework, output is measured by the value of gross production and inputs consist of labour, fixed capital and intermediate inputs. Efficiency in a given sector increases when for a given level of output, the total value of those inputs is reduced. At the aggregate level, the composition of the output matters such that aggregate efficiency reflects the sectoral composition of final demand.

In both those approaches, capital and labour are treated as primary resources even though they are quite obviously different from true natural resources. Capital goods are produced in specialized sectors of the economy. Even labour can be considered a reproducible means of production. Indeed, while natural resources do not need to be produced - although they need to be modified to be valuable to mankind - all other resources have to be produced, and this implies the use of natural resources. The technology used in the production of many capital goods is far better than it was in the past 
in so far as nowadays it requires less natural resources, while the production of human capital requires more of them. We are then all aware that natural or true primary resources enter in the production of the many means of production needed to obtain final outputs, whether directly or indirectly. High efficiency, in other words, is premised on low consumption of true primary resources. To be efficient, therefore, an economy must be parsimonious in the use of the means which require those resources. As goods and services used as intermediate inputs in production, and in replacing and expanding fixed capital directly or indirectly, require primary resources, it is the consumption of primary resources that must be lowered. This line of reasoning, of course, was introduced in the spirit of classical economics by Leontief (1951) in his study of the structure of the American economy over the period 1919-1939. We will adopt the same approach, and make both final consumption and gross investment endogenous in a closed input-output model, and assume that efficiency is obtained by reducing intermediate inputs in production and in both replacing and expanding fixed capital. Before applying that model, let us consider investment in capital goods which is an essential part of the data used in the analysis.

\section{Fixed Investment and the Life of Capital}

The recommended, and most used, method for estimating stocks of fixed, tangible and durable capital (OECD, 1992 and UNECE/Eurostat/OECD, 2004) goes by the name "perpetual inventory". In this approach, the capital stock is considered to be the sum of past investments in capital goods less scrapped or discarded capital goods. For the concept to be useful, it is necessary to make an assumption regarding the time profile of discards. To clarify the implications of this concept we use the following notation:

$K_{j t}$ fixed capital stock in sector $j$ and period $t$

$I_{j t}$ net investment less discards in sector $j$ and period $t$ 
$d_{j t}$ replacement rate

$t_{j}$ number of years of life or turnover time of fixed capital.

According to the concept, the capital stock existing at the end of the current period is the sum of past investments - those made in the current period included - in capital goods less discarded capital goods. Then, if in the destination sector $j$ all capital goods are used for $t_{j}$ years, the capital stock in the same sector is:

(1) $K_{j t}=\left(I_{j t}+d_{j t} K_{j t}\right) \cdot t_{j}$

From this definition, it is easy to derive the condition under which the number of years of life of the existing stock of capital, i.e. $t_{j}$, is constant. First note that the equation also reads:

(2) $1-\left(\frac{I_{j t}}{K_{j t}}+d_{j t}\right) t_{j}=0$,

where $t_{j}$ is the turnover time at the end of period. Now observe that if during the year $t$ there were no investment $\left(I_{j t}+d_{j t} K_{j t}=0\right)$ then the initial stock $K_{j t-1}$ would be one year older at the end of the same year and $t_{j}$ would be higher than at its beginning; while if during the same year, enough investment was made in the economy, then the average number of years of life of the existing capital, $t_{j}$, would be constant. Let us then indicate the amount of fixed investment which would be necessary to keep stable the number of years $t_{j}$ of the existing stock of capital by: $I_{j t}^{*}+d_{j t}^{*} K_{j t}$. With such an amount of investment, the following condition is clearly satisfied:

(3) $\Delta t_{j}=1-\left(\frac{I_{j}^{*}}{K_{j}}+d_{j}^{*}\right) t_{j}=0$.

If actual gross investment $I_{j t}+d_{j t} K_{j t}$ turns out to exceed $I_{j t}^{*}+d_{j t}^{*} K_{j t}$, the actual average number of years of capital decreases and vice-versa. In other, words, by accelerating or decelerating the flow of investment relative to the 
stock, firms can decrease or increase technical progress embodied in new capital goods.

What normally is unknown, however, is the stock of fixed capital rather than its average life and this is precisely our situation. Then the equation above could be used to derive the stock of capital from available data regarding the average life, the rate of replacement and the average amount of investment by destination sector $j$, as follows:

(4) $K_{j t}=\frac{I_{j t}}{\frac{1}{t_{j}}-d_{j t}}$.

The equation shows that the stock is a multiple of the average amount of expansion investment realized in destination sector $j$ where the expanding factor $1 /\left(t_{j}{ }^{-1}-d_{j t}\right)$ is increased when firms prolong the use of the existing capital or increase the rate of replacement.

\section{Productive Efficiency In a Closed Dynamic Model à la Leontief}

To analyse productive efficiency in the use of intermediate and capital goods we will use the following symbols:

$a_{i j}$ is the intermediate input $i$ for one unit of output in sector $j$ (the technical coefficient) for $i=1, N$ and $j=1, N$ where the $N^{\text {th }}$ sector is the household sector which buys intermediate goods and services and provides labour and capital services,

$a_{i N}$ is the input from sector $i$ to sector $N$, or final consumption of products of type $i$ of households, $a_{N j}$ is the input from household sector $N$ to sector $j$

$e_{i}$ is the percentage of total fixed investment expenditure in the economy spent on goods produced by sector $i$ in the given year, 
$c_{j}$ is the amount of replacement investment needed to produce one unity of output in sector $j$,

$a_{i j}+e_{i} c_{j}$ is the annual total flow of goods and services sold by sector $i$ to sector $j$ in order to satisfy intermediate consumption and capital consumption in sector $j$,

$t_{i j}$ is the number of years of life of the capital sold by sector $i$ and used in sector $j$,

$t_{i j} e_{i} c_{j}=b_{i j}$ is the unitary stock of fixed capital in use in sector $j$ and sold by sector $i$,

$a_{i j}=0$, for $i=N ; j=N$ by construction (households do not hire labour)

$b_{i j}=0$, for $i=N ; j=N$ by construction (households do not produce capital goods)

$A$ is a matrix of flow coefficients with endogenous final consumption $B$ is a matrix of stock coefficients with endogenous final consumption

By means of these definitions, we could rephrase the concept of efficiency. For a given level of final output in sector $j$, production efficiency in sector $j$ is increased by decreasing $a_{i j}+e_{i} c_{j}$, or, equivalently, $a_{i j}+b_{i j} / t_{i j}$. Thus a sufficient condition for increased efficiency is a reduction in the combined change in the flow coefficient, the stock coefficient and the duration term, as follows:

(5) $d a_{i j}+\left(\dot{b}_{i j}-\dot{t}_{i j}\right) b_{i j} / t_{i j}<0$,

where the symbols with the dots $\dot{b}_{i j}$ and $\dot{i}_{i j}$ indicate percentage changes. This expression makes clear that it does not matter if one coefficient undergoes a positive change, provided that the other one decreases to provide a negative combined change.

It is obvious that a sufficient condition for increased aggregate efficiency is that condition (5) holds in at least one cell and that the remaining cells are constant. As some cells decrease while others increase in value, one has to 
consider the net result and this can be found by solving the dynamic model. A way of measuring efficiency, therefore, can be obtained by estimating the $b_{i j}$ 's coefficients and solving the resulting dynamic model in order to find the maximum rate of uniform growth in the economy. While we claim no originality, we argue that this old approach is able to highlight the role of productive inputs reduction i.e. increased efficiency in the growth process. By defining as $\lambda$ the uniform rate of economic growth, or the rate which assures that the economy grows in a balanced way, one arrives at the well known Leontief's closed dynamic model (Leontief, 1985):

(6) $x=A x+\lambda B x$.

To focus more closely on how a change in efficiency $d a_{i j}+\left(\dot{b}_{i j}-\dot{t}_{i j}\right) b_{i j} / t_{i j} \neq 0$ hinges upon the growth rate, we express the uniform growth rate $\lambda$ in terms of both the model's value and technical coefficients in the Appendix.

To summarize the above discussion, we observe, firstly, that there is a practical advantage to be obtained by constructing a dynamic model based on the idea that capital stock coefficients can be obtained from data on replacement, investment and duration, as follows:

(7) $b_{i j}=t_{i j} e_{i} c_{j}$.

Secondly, we argue that productive efficiency implies a higher uniform or balanced growth rate that can be derived from what Leontief (1985) called the closed version of the dynamic model which is basically what we use in the analysis of efficiency. We argue, in particular, that productive efficiency is the highest when matrices $A$ and $B$ are such that the implied rate of uniform growth in the economy is maximal. The model is not entirely closed as if it were so, the matrix equation above $(I-A-\lambda B) x=0$ would have multiple solutions. In this case, actual output could not be uniquely determined unless boundary conditions on the availability of natural resources were provided. In the section below, therefore, we will use a 
model with endogenous final consumption and capital formation which, being not entirely closed, is capable of having one solution only.

Provided that the model is a open one, the properties of the coefficient matrices $A$ and $B$ are such that there exists only one single growth rate $\lambda$ which makes the equation capable of being solved by a positive vector $x$. As final consumption is considered as an input in the sector which produces labour and capital services, total production meets all direct and indirect needs required by the expansion of the economy at the uniform growth rate $\lambda$. To find such special positive solution, the unique making economic sense, is easy. The model can be written as a standard eigen-equation of the matrix $(I-A)^{-1} B$ :

(8) $\frac{1}{\lambda} x=(I-A)^{-1} B x$.

Let's indicate with $\rho$ the first or maximal eigenvalue and with $\bar{x}$ the corresponding eigenvector:

(9) $\rho \bar{x}=(I-A)^{-1} B \bar{x}$.

It is well known that according to the Frobenius theorem, the largest root of $(I-A)^{-1} B$ is always simple and positive, and so are also all the elements of the associate vector $\bar{x}^{1}$. From the above it follows that the lower the maximal eigenvalue $\rho$, the higher the rate of balanced growth $\lambda$ in the economy and thus the greater the efficiency. As we assume that changes in the single flow, and stock coefficients, hinge upon efficiency, it is much more practical to refer to the Frobenius eigenvalue rather than to the individual coefficient, although there are coefficients whose change

\footnotetext{
${ }^{1}$ According to the same theorem, if an arbitrary positive vector is repeatedly pre-multiplied by such a matrix, then the result tends towards the positive eigenvector $\bar{x}$. The speed of the convergence depends on the level of the second eigenvalue $\left(\lambda_{2}\right)$ relative to that of the first $\left(\lambda_{1}\right)$, as the closer the two values, the lower the speed of convergence. Thus, the worst possible o less efficient case is obtained when $\lambda_{1}$ is high and the difference $\lambda_{1}-\lambda_{2}$ large, as the available technology reaches rapidly the balanced path characterized by a low rate of balanced growth. Brody (1997) has recently investigated the relation between the two largest eigenvalues and claimed that their relation, and thus the speed of convergence, is related to the size of the coefficient matrix.
} 
$d a_{i j}+\left(\dot{k}_{i j}-\dot{t}_{i j}\right) k_{i j} / t_{i j}$ have a more than average bearing on the eigenvalue ${ }^{2}$. Also, differences in productive efficiency that can be observed across space and over time can be ascribed to differences in those coefficients. Differences in productive efficiency, therefore, can be globally assessed also by the associate Frobenious eigenvalue $\rho$ of matrix $(I-A)^{-1} B$. If we were interested in the overall impact, the maximal eigenvalue offers a perfect answer. A well known property of the maximal eigenvalue of $(I-A)^{-1} B$ is that the reciprocal of the eigenvalues which are different from $\rho$, are lower in modulus thus yielding higher growth rates. The associate eigenvectors, however, are not positive in all their elements thus the growth rate associated to the maximal eigenvalue is the lowest of all, but it is also the only one sustainable in the long run and thus the only one making economic sense. For any change in the flow and capital coefficient matrices, which occurs when $d a_{i j}+\left(\dot{b}_{i j}-\dot{t}_{i j}\right) b_{i j} / t_{i j} \neq 0$ in at least one case, the computation of the dominant eigenvalue immediately translates the change in the coefficients into the change in the rate of balanced growth.

\section{Productive efficiency in selected European countries}

Using the theoretical framework above, we have analyzed productive efficiency in 16 European countries for which EUROSTAT provides inputoutput tables for 30 sectors . Table 1 details the fourteen out of sixteen countries which have published the tables for 2000.

\footnotetext{
${ }^{2}$ More on this in the last section.
} 
Table 1. Countries Publishing Eurostat Input-Output Tables: 2000.

\begin{tabular}{|l|l|l|}
\hline 1 & Austria & 2000 \\
2 & Belgium & $2000^{*}$ \\
3 & Czech Republic & 2000 \\
4 & Denmark & 2000 \\
5 & Estonia & 2000 \\
6 & Finland & 2000 \\
7 & Germany & 2000 \\
8 & Ireland & 2000 \\
9 & Italy & 2000 \\
10 & Lithuania & 2000 \\
11 & Norway & $2001^{*}$ \\
12 & Portugal & $1999^{*}$ \\
13 & Slovakia & 2000 \\
14 & Slovenia & $2000^{*}$ \\
15 & Spain & 2000 \\
16 & Sweden & 2000 \\
\hline
\end{tabular}

In Table 1 above, "*” means that financial intermediate services indirectly measured (FISIM) are dealt with using the old methodology i.e. by adding to the standard 30 sectors a special sector that reports on the total undistributed amount of financial services. Notable omissions in Table 1 are large economies such as France, UK and the Netherlands due to a lack of data on consumption of fixed capital by sector ${ }^{3}$. The same problem occurred for the cases of Italy and Spain, but for these two countries we decided to use supplementary data provided by the Italian Statistical Central Office (ISTAT) to estimate the consumption of fixed capital by sector ${ }^{4}$. This source provides, in particular, detailed figures regarding the life-span of specific fixed-capital goods which allows us to estimate the coefficients $t_{i j}$ as shown in Table 2.

\footnotetext{
${ }^{3}$ In the case of France, data is only provided on the consumption of fixed capital for several branches.

${ }^{4}$ ISTAT publishes data on replacement and capital stock from 1980. It also provides information regarding the duration of nine different types of capital goods for the thirty branches of economic activity. Other countries do the same (UNECE/Eurostat/OECD, 2004). This wealth of information has been utilised for all the European countries for which replacement figures are available.
} 
Table 2. The service-life of fixed-capital goods. BRANCHES OF ORIGIN

SECTORS (suppliers)

01 Agriculture, hunting and forestry

02 Fishing

03 Mining and quarrying of energy producing materials

04 Mining and quarrying except energy producing materials

05 Manufacture of food products; beverages and tobacco

06 Manufacture of textiles and textile products

07 Manufacture of leather and leather products

08 Manufacture of wood and wood products

09 Manufacture of pulp, paper and paper products; publishing and printing

10 Manufacture of coke, refined petroleum products and nuclear fuel

11 Manufacture of chemicals, chemical products and man-made fibres

12 Manufacture of rubber and plastic products

13 Manufacture of other non-metallic mineral products

14 Manufacture of basic metals and fabricated metal products

15 Manufacture of machinery and equipment n.e.c. $\left(^{*}\right)$

16 Manufacture of electrical and optical equipment $\left({ }^{*}\right)$

17 Manufacture of transport equipment $\left({ }^{*}\right)$

18 Manufacturing n.e.c. $\left({ }^{*}\right)$

19 Electricity, gas and water supply

20 Construction $\left({ }^{*}\right)$

Wholesale and retail trade; repair of motor vehicles, motorcyc, personal

21 and household goods (*)

22 Hotels and restaurants

23 Transport, storage and communication

24 Financial intermediation

25 Real estate, renting and business activities

26 Public administration and defence; compulsory social security

27 Education

28 Health and social work

29 Other community, social, personal service activities

30 Activities of households

(*) Estimation based on ISTAT data source.
DESTINATION BRANCHES (purchasers)

\begin{tabular}{l|l|l|l|l|l|l|l|l|l|l|l|l|l|l|l|l|l|l|l|l|l|l|l|l|l|l|l|l|l|}
01 & 02 & 03 & 04 & 05 & 06 & 07 & 08 & 09 & 10 & 11 & 12 & 13 & 14 & 15 & 16 & 17 & 18 & 19 & 20 & 21 & 22 & 23 & 24 & 25 & 26 & 27 & 28 & 29 & 30 \\
\hline
\end{tabular}

$\begin{array}{llllllllllllllllllllllllllllll}1 & 1 & 1 & 1 & 1 & 1 & 1 & 1 & 1 & 1 & 1 & 1 & 1 & 1 & 1 & 1 & 1 & 1 & 1 & 1 & 1 & 1 & 1 & 1 & 1 & 1 & 1 & 1 & 1 & 1\end{array}$ $\begin{array}{llllllllllllllllllllllllllllll}1 & 1 & 1 & 1 & 1 & 1 & 1 & 1 & 1 & 1 & 1 & 1 & 1 & 1 & 1 & 1 & 1 & 1 & 1 & 1 & 1 & 1 & 1 & 1 & 1 & 1 & 1 & 1 & 1 & 1\end{array}$ $\begin{array}{llllllllllllllllllllllllllllll}3 & 3 & 3 & 3 & 3 & 3 & 3 & 3 & 3 & 3 & 3 & 3 & 3 & 3 & 3 & 3 & 3 & 3 & 3 & 3 & 3 & 3 & 3 & 3 & 3 & 3 & 3 & 3 & 3 & 3\end{array}$ $\begin{array}{lllllllllllllllllllllllllllll}1 & 1 & 1 & 1 & 1 & 1 & 1 & 1 & 1 & 1 & 1 & 1 & 1 & 1 & 1 & 1 & 1 & 1 & 1 & 1 & 1 & 1 & 1 & 1 & 1 & 1 & 1 & 1 & 1\end{array}$ $\begin{array}{llllllllllllllllllllllllllllll}1 & 1 & 1 & 1 & 1 & 1 & 1 & 1 & 1 & 1 & 1 & 1 & 1 & 1 & 1 & 1 & 1 & 1 & 1 & 1 & 1 & 1 & 1 & 1 & 1 & 1 & 1 & 1 & 1 & 1\end{array}$ $\begin{array}{llllllllllllllllllllllllllllll}1 & 1 & 1 & 1 & 1 & 1 & 1 & 1 & 1 & 1 & 1 & 1 & 1 & 1 & 1 & 1 & 1 & 1 & 1 & 1 & 1 & 1 & 1 & 1 & 1 & 1 & 1 & 1 & 1 & 1\end{array}$ $\begin{array}{llllllllllllllllllllllllllllll}10 & 10 & 10 & 10 & 10 & 10 & 10 & 10 & 10 & 10 & 10 & 10 & 10 & 10 & 10 & 10 & 10 & 10 & 10 & 10 & 10 & 10 & 10 & 10 & 10 & 10 & 10 & 10 & 10 & 10\end{array}$ $\begin{array}{llllllllllllllllllllllllllllll}3 & 3 & 3 & 3 & 3 & 3 & 3 & 3 & 3 & 3 & 3 & 3 & 3 & 3 & 3 & 3 & 3 & 3 & 3 & 3 & 3 & 3 & 3 & 3 & 3 & 3 & 3 & 3 & 3 & 3\end{array}$ $\begin{array}{lllllllllllllllllllllllllllllll}1 & 1 & 1 & 1 & 1 & 1 & 1 & 1 & 1 & 1 & 1 & 1 & 1 & 1 & 1 & 1 & 1 & 1 & 1 & 1 & 1 & 1 & 1 & 1 & 1 & 1 & 1 & 1 & 1 & 1\end{array}$ $\begin{array}{llllllllllllllllllllllllllllll}3 & 3 & 3 & 3 & 3 & 3 & 3 & 3 & 3 & 3 & 3 & 3 & 3 & 3 & 3 & 3 & 3 & 3 & 3 & 3 & 3 & 3 & 3 & 3 & 3 & 3 & 3 & 3 & 3 & 3\end{array}$ $\begin{array}{llllllllllllllllllllllllllllll}3 & 3 & 3 & 3 & 3 & 3 & 3 & 3 & 3 & 3 & 3 & 3 & 3 & 3 & 3 & 3 & 3 & 3 & 3 & 3 & 3 & 3 & 3 & 3 & 3 & 3 & 3 & 3 & 3 & 3\end{array}$ $\begin{array}{llllllllllllllllllllllllllllll}3 & 3 & 3 & 3 & 3 & 3 & 3 & 3 & 3 & 3 & 3 & 3 & 3 & 3 & 3 & 3 & 3 & 3 & 3 & 3 & 3 & 3 & 3 & 3 & 3 & 3 & 3 & 3 & 3 & 3\end{array}$ \begin{tabular}{llllllllllllllllllllllllllllll}
15 & 15 & 15 & 15 & 15 & 15 & 15 & 15 & 15 & 15 & 15 & 15 & 15 & 15 & 15 & 15 & 15 & 15 & 15 & 15 & 15 & 15 & 15 & 15 & 15 & 15 & 15 & 15 & 15 & 15 \\
\hline
\end{tabular} $\begin{array}{llllllllllllllllllllllllllllllll}18 & 18 & 18 & 18 & 18 & 18 & 18 & 18 & 18 & 18 & 18 & 18 & 18 & 18 & 18 & 18 & 18 & 18 & 18 & 18 & 18 & 18 & 18 & 18 & 18 & 18 & 18 & 18 & 18 & 18\end{array}$ $\begin{array}{llllllllllllllllllllllllllllllll}7 & 7 & 7 & 7 & 7 & 7 & 7 & 7 & 7 & 7 & 7 & 7 & 7 & 7 & 7 & 7 & 7 & 7 & 7 & 7 & 7 & 7 & 7 & 7 & 7 & 7 & 7 & 7 & 7 & 7\end{array}$

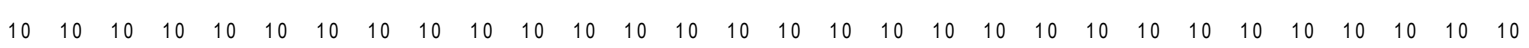

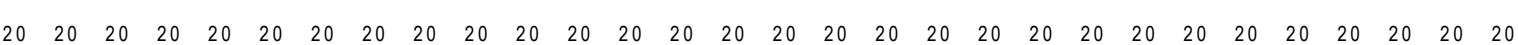
$\begin{array}{llllllllllllllllllllllllllllll}1 & 1 & 1 & 1 & 1 & 1 & 1 & 1 & 1 & 1 & 1 & 1 & 1 & 1 & 1 & 1 & 1 & 1 & 1 & 1 & 1 & 1 & 1 & 1 & 1 & 1 & 1 & 1 & 1 & 1\end{array}$ $\begin{array}{llllllllllllllllllllllllllllll}51 & 35 & 35 & 35 & 36 & 35 & 35 & 35 & 35 & 35 & 35 & 35 & 35 & 35 & 35 & 35 & 35 & 35 & 40 & 35 & 65 & 65 & 50 & 65 & 79 & 60 & 57 & 35 & 56 & 0\end{array}$ $\begin{array}{lllllllllllllllllllllllllllllllllllllll}5 & 5 & 5 & 5 & 5 & 5 & 5 & 5 & 5 & 5 & 5 & 5 & 5 & 5 & 5 & 5 & 5 & 5 & 5 & 5 & 5 & 5 & 5 & 5 & 5 & 5 & 5 & 5 & 5 & 5\end{array}$ $\begin{array}{llllllllllllllllllllllllllllll}5 & 5 & 5 & 5 & 5 & 5 & 5 & 5 & 5 & 5 & 5 & 5 & 5 & 5 & 5 & 5 & 5 & 5 & 5 & 5 & 5 & 5 & 5 & 5 & 5 & 5 & 5 & 5 & 5 & 5 \\ 5 & 5 & 5 & 5 & 5 & 5 & 5 & 5 & 5 & 5 & 5 & 5 & 5 & 5 & 5 & 5 & 5 & 5 & 5 & 5 & 5 & 5 & 5 & 5 & 5 & 5 & 5 & 5 & 5 & 5\end{array}$ $\begin{array}{llllllllllllllllllllllllllllll}5 & 5 & 5 & 5 & 5 & 5 & 5 & 5 & 5 & 5 & 5 & 5 & 5 & 5 & 5 & 5 & 5 & 5 & 5 & 5 & 5 & 5 & 5 & 5 & 5 & 5 & 5 & 5 & 5 & 5\end{array}$ $\begin{array}{llllllllllllllllllllllllllllll}5 & 5 & 5 & 5 & 5 & 5 & 5 & 5 & 5 & 5 & 5 & 5 & 5 & 5 & 5 & 5 & 5 & 5 & 5 & 5 & 5 & 5 & 5 & 5 & 5 & 5 & 5 & 5 & 5 & 5\end{array}$ $\begin{array}{llllllllllllllllllllllllllllll}5 & 5 & 5 & 5 & 5 & 5 & 5 & 5 & 5 & 5 & 5 & 5 & 5 & 5 & 5 & 5 & 5 & 5 & 5 & 5 & 5 & 5 & 5 & 5 & 5 & 5 & 5 & 5 & 5 & 5\end{array}$ $\begin{array}{llllllllllllllllllllllllllllll}5 & 5 & 5 & 5 & 5 & 5 & 5 & 5 & 5 & 5 & 5 & 5 & 5 & 5 & 5 & 5 & 5 & 5 & 5 & 5 & 5 & 5 & 5 & 5 & 5 & 5 & 5 & 5 & 5 & 5\end{array}$ $\begin{array}{llllllllllllllllllllllllllllll}5 & 5 & 5 & 5 & 5 & 5 & 5 & 5 & 5 & 5 & 5 & 5 & 5 & 5 & 5 & 5 & 5 & 5 & 5 & 5 & 5 & 5 & 5 & 5 & 5 & 5 & 5 & 5 & 5 & 5 \\ 5 & 5 & 5 & 5 & 5 & 5 & 5 & 5 & 5 & 5 & 5 & 5 & 5 & 5 & 5 & 5 & 5 & 5 & 5 & 5 & 5 & 5 & 5 & 5 & 5 & 5 & 5 & 5 & 5 & 5\end{array}$ $\begin{array}{llllllllllllllllllllllllllllll}5 & 5 & 5 & 5 & 5 & 5 & 5 & 5 & 5 & 5 & 5 & 5 & 5 & 5 & 5 & 5 & 5 & 5 & 5 & 5 & 5 & 5 & 5 & 5 & 5 & 5 & 5 & 5 & 5 & 5\end{array}$ 
In the previous section we argued that by accelerating or decelerating the flow of investment relative to the stock, firms can tune the average number of years of their stock of capital and thus tune technical progress embodied in new capital goods. This implies that the $t_{i j}$ 's are neither constant over time nor uniform across the different economies. This instability has obvious implications for the amount of fixed capital in the different circumstances. Obviously, the table above is not easy to estimate for each country, since related information is hardly available. Thus, we assume the service life values or simply the number of years suggested are valid for all the countries.

From the EUROSTAT tables and the data in Table 2 we have derived the matrices $(I-A)^{-1} B$ and, in turn, the corresponding dominant eigenvalues $\rho$. Table 3 shows the value of the dominant eigenvalue, the corresponding rate of balanced growth and the actual average rate of growth in the period 1998-2007 provided by EUROSTAT for each country. The last column in the same Table shows the differences between the actual rate of growth and the one computed from the dynamic model. Several comments are in order. First of all, it appears that the balanced growth rate is a poor predictor of actual growth and, indeed, there seems to be an inverse relation between the two rates, a relation which is more evident if the two outlier cases (Sweden and Norway) are removed from the scattergram (Figure 1). If this is done, Italy is shown to have the highest balanced growth rate but the lowest actual growth rate. Ireland has the opposite. One could further argue that the rate of actual growth (col. c) can be decomposed into the rate of balanced growth (col. b) and the residual (col. d) i.e. the difference between the actual output composition and the one corresponding to the balanced growth path. As illustrated in the same figure, actual average growth rates show a higher dispersion than that found in the uniform growth rates derived from the model. It appears that seven countries were able to grow at an average rate which is higher - in some cases markedly higher - than the balanced one. 
Table 3. Maximum eigenvalues and rates of economic growth.

\begin{tabular}{|c|c|c|c|c|}
\hline Country & $\begin{array}{c}\text { Max. } \\
\text { Eigenvalue }\end{array}$ & $\begin{array}{c}\text { (b) } \\
\text { \% Rate of } \\
\text { balanced } \\
\text { growth }\end{array}$ & $\begin{array}{c}\text { (c) } \\
\text { \% Rate of } \\
\text { actual growth } \\
\text { (average 1998-07) }\end{array}$ & (d) = (c) - (b) \\
Difference \\
\hline Ireland & 34,30 & 2,92 & 7,46 & 4,54 \\
Lithuania & 37,99 & 2,63 & 6,79 & 4,16 \\
Slovakia & 33,78 & 2,96 & 6,56 & 3,60 \\
Slovenia & 31,34 & 3,19 & 4,95 & 1,76 \\
Spain & 30,73 & 3,25 & 4,29 & 1,04 \\
Finland & 28,08 & 3,56 & 3,82 & 0,26 \\
Czech Republic & 34,39 & 2,91 & 3,59 & 0,68 \\
Sweden & 30,14 & 3,32 & 3,27 & $-0,05$ \\
Norway & 20,82 & 4,80 & 3,24 & $-1,56$ \\
Austria & 22,91 & 4,36 & 2,53 & $-1,83$ \\
Belgium & 29,35 & 3,41 & 2,42 & $-0,99$ \\
Denmark & 26,56 & 3,76 & 2,24 & $-1,52$ \\
Portugal & 31,25 & 3,20 & 2,04 & $-1,16$ \\
Germany & 32,16 & 3,11 & 2,02 & $-1,09$ \\
Italy & 29,75 & 3,36 & 1,55 & $-1,81$ \\
\hline
\end{tabular}

Figure 01. Actual rates of growth and balanced growth rate.

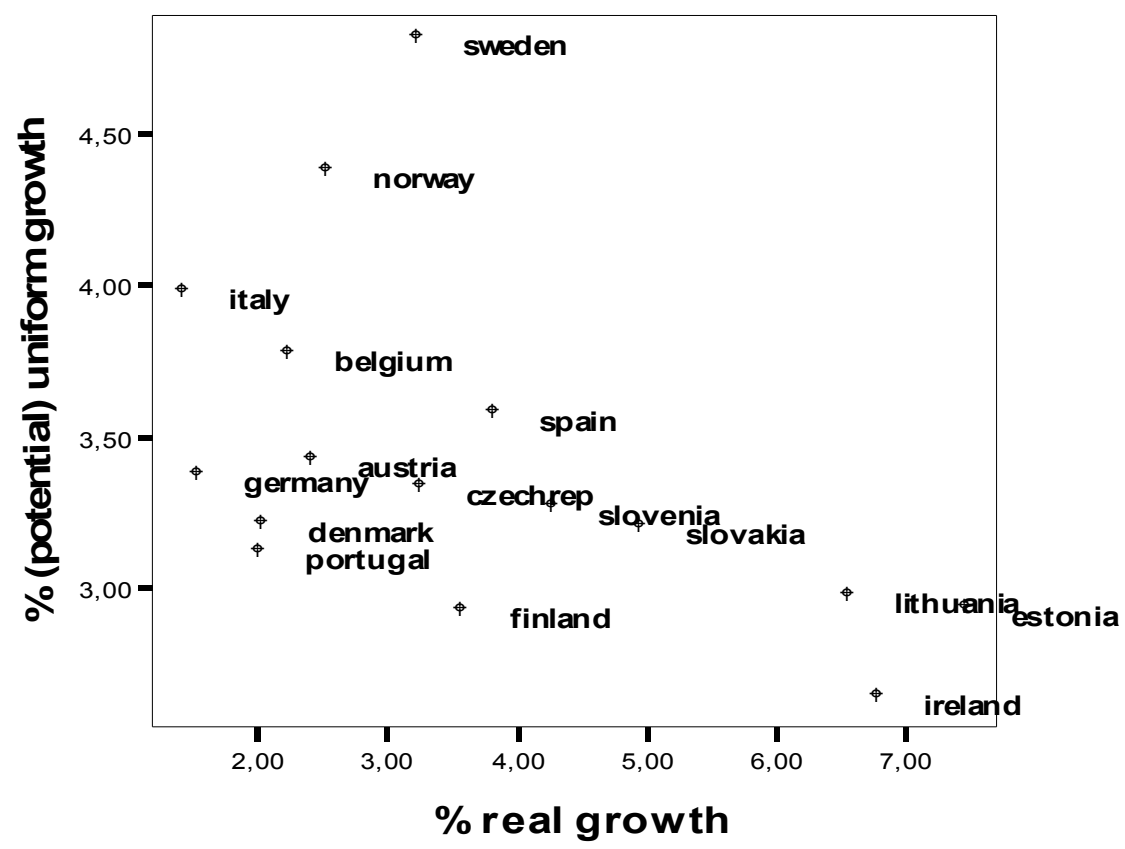


The differences clearly require an explanation. We first observe that since the actual structure of production need not be that implied by the dominant eigenvector ${ }^{5}$, it is necessary to verify whether the differences between the actual and the balanced growth rates are related to the differences existing between the actual production structure and that implied by the eigenvector measured with the Theil's index of similarity:

$$
I_{T}^{k}=\sum_{j} \bar{x}_{j}^{k} \ln \left(\frac{\bar{x}_{j}^{k}}{x_{j}^{k}}\right)
$$

where:

$\bar{x}_{j}^{k} \quad$ output share of sector $j$ in country $k$ in the balanced growth

$x_{j}^{k} \quad$ output share of sector $j$ in country $k$ actually observed.

Indeed, it can be argued that growth in the economy as a whole actually reflects total factor productivity i.e. including varying efficiency in the different sectors and also the economy's output composition. The Theil's index takes a value close to zero when actual growth and balanced growth rates are equal, and increases when are not Table 4 shows that in many cases the index has a value that is rather low, and that the few exceptions are found in countries where the difference between actual and balanced growth are larger. Figure 2 shows that there is some evidence of a positive association between the two variables (the correlation coefficient is equal to 0.595 and to 0.653 if Estonia is excluded).

\footnotetext{
${ }^{5}$ The dominant eigenvector is the eigenvector associated with the dominant eigenvalue.
} 
Table 04. Theil's index of similarity.

\begin{tabular}{|c|c|c|}
\hline Country & Theil's Index & $\begin{array}{c}\text { Difference between } \\
\text { actual and } \\
\text { balanced growth } \\
\text { rates }\end{array}$ \\
\hline Estonia & 0,1132 & 4,54 \\
Ireland & 0,2435 & 4,16 \\
Lithuania & 0,1179 & 3,60 \\
Slovakia & 0,1005 & 1,76 \\
Slovenia & 0,0831 & 1,04 \\
Finland & 0,0944 & 0,68 \\
Spain & 0,0345 & 0,26 \\
Czech Republic & 0,0482 & $-0,05$ \\
\hline Austria & 0,0393 & $-0,99$ \\
Portugal & 0,1375 & $-1,09$ \\
Denmark & 0,0740 & $-1,16$ \\
Belgium & 0,0898 & $-1,52$ \\
Sweden & 0,0646 & $-1,56$ \\
Germany & 0,0543 & $-1,81$ \\
Norway & 0,1469 & $-1,83$ \\
Italy & 0,0402 & $-2,53$ \\
\hline
\end{tabular}

Figure 2. Absolute differences between actual and balanced growth rate and Theil's index of similarity.

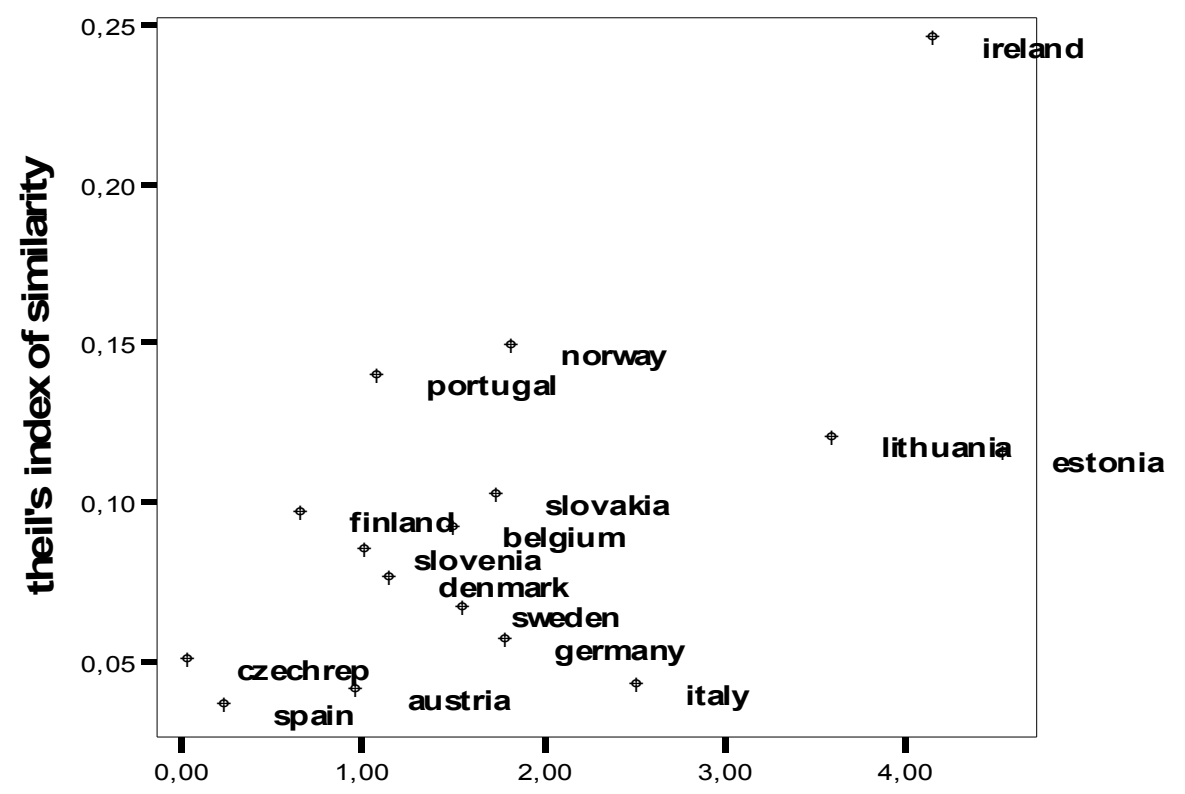

absolute differences be twe en rates of growth 


\section{Principal Components of the Eigenvectors}

To deepen our analysis, we have tried to ascertain whether there are sectors which, being under or overrepresented in the actual production structure, can be deemed to be more responsible than others for the difference between the actual and the balanced growth rates. This was achieved by applying principal component analysis to the output structure in the different countries. Seven components have been extracted and Table 5 displays the main results in the principal components analysis with varimax rotation over the structure of the eigenvectors of each country. The "Total" column gives the variance in the original variables accounted for by each component. The "Share of variance" column gives the percentage share of total variance accounted for by each component. The last column shows the cumulative share of variance accounted for by the single components.

Table 5. Extraction of (rotated) components.

\begin{tabular}{|c|c|c|c|}
\hline \multirow[t]{2}{*}{ Component } & \multicolumn{3}{|c|}{ Rotated sum of squared loadings } \\
\hline & Total & $\begin{array}{l}\text { Share of } \\
\text { variance }\end{array}$ & $\begin{array}{c}\text { Cumulative } \\
\text { share of } \\
\text { variance }\end{array}$ \\
\hline 1 & 7,9 & 0.25 & 0.25 \\
\hline 2 & 6,5 & 0.21 & 0.46 \\
\hline 3 & 3,6 & 0.11 & 0.58 \\
\hline 4 & 2,7 & 0.08 & 0.67 \\
\hline 5 & 2,4 & 0.07 & 0.75 \\
\hline 6 & 2,2 & 0,07 & 0.82 \\
\hline 7 & 1,9 & 0,06 & 0.88 \\
\hline
\end{tabular}

There are two dominant components, each one accounting for more than $20 \%$ of total variance. We can characterize the components according to their factorial loads in the rotated component matrix by correlating each component to the shares in the eigenvector. Table 6 shows the factorial loads for each component and sector. If the factorial load regarding 
component $p$ and eigenvector's element $\bar{x}_{j}$ is close to 1 , a country with a high $\bar{x}_{j}$ eigenvector's element will tend to show a high score in component $p$. On the contrary, if the factorial load related to component $p$ and the eigenvector's element $\bar{x}_{j}$ is close to -1 , a country with a high $\bar{x}_{j}$ eigenvector's element will tend to show a low score in factor $p$. Finally, if the factorial load between factor $p$ and eigenvector's element $\bar{x}_{j}$ is closed to 0 , the score of component $p$ will be rather independent from such an eigenvector's element $\bar{x}_{j}$. Table 6 shows the factorial loads for each component and sector. 
Table 6. Factorial loads by component and sector.

\begin{tabular}{|c|c|c|c|c|c|c|c|}
\hline \multirow[b]{2}{*}{ Sector } & \multicolumn{7}{|c|}{ Component } \\
\hline & 1 & 2 & 3 & 4 & 5 & 6 & 7 \\
\hline 1 Agriculture, hunting and forestry & 0,897 & 0,013 & $-0,235$ & $-0,231$ & 0,021 & $-0,024$ & $-0,102$ \\
\hline 2 Fishing & $-0,105$ & $-0,176$ & 0,029 & 0,225 & $-0,132$ & $-0,079$ & 0,882 \\
\hline $\begin{array}{l}3 \text { Mining and quarrying of energy } \\
\text { producing materials }\end{array}$ & 0,865 & 0,138 & 0,150 & $-0,196$ & 0,103 & $-0,307$ & $-0,075$ \\
\hline $\begin{array}{l}4 \text { Mining and quarrying except energy } \\
\text { producing materials }\end{array}$ & 0,002 & $-0,136$ & $-0,865$ & $-0,250$ & 0,112 & 0,094 & $-0,079$ \\
\hline $\begin{array}{l}5 \text { Manufacture of food products; } \\
\text { beverages and tobacco }\end{array}$ & 0,875 & 0,081 & $-0,339$ & 0,021 & 0,036 & 0,094 & 0,212 \\
\hline $\begin{array}{l}6 \text { Manufacture of textiles and textile } \\
\text { products }\end{array}$ & 0,461 & 0,461 & $-0,186$ & 0,193 & 0,084 & 0,631 & $-0,054$ \\
\hline $\begin{array}{l}7 \text { Manufacture of leather and leather } \\
\text { products }\end{array}$ & 0,678 & 0,265 & $-0,041$ & 0,322 & $-0,149$ & 0,396 & $-0,135$ \\
\hline $\begin{array}{l}8 \text { Manufacture of wood and wood } \\
\text { products }\end{array}$ & 0,627 & $-0,604$ & 0,138 & $-0,114$ & $-0,100$ & $-0,202$ & 0,222 \\
\hline $\begin{array}{l}9 \text { Manufacture of pulp, paper and } \\
\text { paper products; publishing and printing }\end{array}$ & $-0,227$ & 0,130 & 0,764 & $-0,290$ & $-0,126$ & 0,271 & 0,095 \\
\hline $\begin{array}{l}10 \text { Manufacture of coke, refined } \\
\text { petroleum products and nuclear fuel }\end{array}$ & $-0,071$ & 0,900 & 0,338 & 0,105 & 0,009 & 0,014 & 0,061 \\
\hline $\begin{array}{l}11 \text { Manufacture of chemicals, chemical } \\
\text { products and man-made fibres }\end{array}$ & 0,771 & 0,507 & 0,014 & $-0,070$ & $-0,019$ & 0,204 & $-0,011$ \\
\hline $\begin{array}{l}12 \text { Manufacture of rubber and plastic } \\
\text { products }\end{array}$ & 0,832 & 0,253 & $-0,053$ & $-0,181$ & $-0,228$ & 0,117 & $-0,208$ \\
\hline $\begin{array}{l}13 \text { Manufacture of other non-metallic } \\
\text { mineral products }\end{array}$ & 0,477 & 0,635 & 0,133 & 0,252 & 0,412 & 0,062 & $-0,191$ \\
\hline $\begin{array}{l}14 \text { Manufacture of basic metals and } \\
\text { fabricated metal products }\end{array}$ & 0,220 & 0,914 & 0,207 & $-0,060$ & $-0,067$ & 0,057 & $-0,027$ \\
\hline $\begin{array}{l}15 \text { Manufacture of machinery and } \\
\text { equipment n.e.c. }\end{array}$ & 0,187 & 0,584 & 0,388 & $-0,226$ & 0,269 & $-0,438$ & $-0,113$ \\
\hline $\begin{array}{l}16 \text { Manufacture of electrical and } \\
\text { optical equipment }\end{array}$ & 0,093 & 0,364 & $-0,005$ & $-0,192$ & $-0,856$ & $-0,024$ & 0,034 \\
\hline 17 Manufacture of transport equipment & $-0,290$ & 0,372 & $-0,355$ & 0,193 & 0,537 & 0,147 & 0,258 \\
\hline 18 Manufacturing n.e.c. & $-0,002$ & $-0,298$ & $-0,879$ & 0,249 & $-0,031$ & 0,054 & $-0,117$ \\
\hline 19 Electricity, gas and water supply & 0,609 & 0,479 & $-0,100$ & $-0,186$ & 0,057 & $-0,505$ & $-0,137$ \\
\hline $\begin{array}{l}20 \text { Construction } \\
21 \text { Wholesale and retail trade; repair }\end{array}$ & 0,151 & 0,566 & 0,013 & 0,033 & 0,653 & $-0,188$ & $-0,026$ \\
\hline $\begin{array}{l}\text { of motor vehicles, personal and } \\
\text { household goods }\end{array}$ & 0,292 & $-0,349$ & 0,130 & 0,186 & 0,151 & 0,735 & $-0,079$ \\
\hline 22 Hotels and restaurants & $-0,224$ & 0,005 & $-0,232$ & 0,818 & 0,147 & 0,114 & 0,211 \\
\hline $\begin{array}{l}23 \text { Transport, storage and } \\
\text { communication }\end{array}$ & 0,057 & $-0,334$ & 0,156 & $-0,220$ & $-0,648$ & $-0,367$ & 0,414 \\
\hline 24 Financial intermediation & $-0,582$ & $-0,102$ & $-0,354$ & 0,236 & $-0,156$ & $-0,132$ & $-0,615$ \\
\hline $\begin{array}{l}25 \text { Real estate, renting and business } \\
\text { activities }\end{array}$ & $-0,869$ & 0,026 & 0,011 & $-0,067$ & $-0,031$ & $-0,142$ & $-0,111$ \\
\hline $\begin{array}{l}26 \text { Public administration and defence; } \\
\text { compulsory social security }\end{array}$ & $-0,203$ & $-0,673$ & 0,002 & $-0,529$ & $-0,022$ & 0,044 & 0,242 \\
\hline 27 Education & $-0,408$ & $-0,612$ & 0,295 & $-0,199$ & 0,007 & 0,316 & 0,329 \\
\hline 28 Health and social work & $-0,764$ & $-0,524$ & 0,104 & $-0,178$ & 0,127 & $-0,044$ & 0,186 \\
\hline $\begin{array}{l}29 \text { Other community, social, personal } \\
\text { service activities }\end{array}$ & $-0,459$ & $-0,332$ & 0,712 & 0,059 & 0,102 & $-0,039$ & $-0,157$ \\
\hline 30 Activities of households & $-0,085$ & 0,060 & 0,054 & 0,888 & 0,209 & 0,186 & 0,009 \\
\hline 31 Add_value \& consumption & $-0,381$ & $-0,873$ & 0,045 & 0,135 & $-0,015$ & 0,171 & $-0,010$ \\
\hline
\end{tabular}

These results show that the first component is positively related to agriculture, and foodstuff manufacturing, while being in a negative relation with real estate, renting and business services. The second component is 
mainly positively related to the energy supplying sector and the manufacture of metal products, and negatively to the households sector. Table 7 displays the scores of the seven factors in the different countries:

Table 7. Scores of the countries for each component.

\begin{tabular}{|l|c|c|c|c|c|c|c|}
\hline & FACTOR & FACTOR & FACTOR & FACTOR & FACTOR & FACTOR & FACTOR \\
& $\mathbf{1}$ & $\mathbf{2}$ & $\mathbf{3}$ & $\mathbf{4}$ & $\mathbf{5}$ & $\mathbf{6}$ & $\mathbf{7}$ \\
\hline Austria & $-0,40800$ & $-0,54100$ & 0,29923 & 0,62587 & 0,08697 & $-0,05259$ & $-1,16797$ \\
Belgium & $-0,80683$ & $\mathbf{0 , 6 3 9 3 5}$ & $-\mathbf{0 , 3 6 8 1 7}$ & $-0,41642$ & 0,50108 & 0,54027 & 0,36967 \\
Czech R. & $\mathbf{0 , 6 7 7 3 6}$ & 1,44057 & 0,00772 & $-0,22974$ & $-0,32604$ & $-1,22780$ & $-0,61473$ \\
Denmark & $-0,68824$ & $-1,14240$ & 1,20720 & $-0,36768$ & $-0,03846$ & $-0,38830$ & $-0,48795$ \\
Estonia & $\mathbf{0 , 5 3 7 4 8}$ & $\mathbf{0 , 9 1 1 5 7}$ & 0,21171 & $-0,21758$ & $-3,18627$ & 0,33487 & 0,53816 \\
Finland & $-0,43319$ & $-0,51862$ & 1,00503 & $-0,98044$ & $-0,06418$ & 0,06338 & $-0,37701$ \\
Germany & $-0,96029$ & $-0,18975$ & 0,41739 & 0,23331 & 0,29765 & $-0,11071$ & $-1,41917$ \\
Ireland & $-0,75244$ & $-0,84228$ & $-3,38556$ & $-0,14167$ & $-0,42463$ & 0,22129 & $-0,29633$ \\
Italy & 0,16831 & 0,05981 & 0,31248 & 1,83003 & $-0,46248$ & 0,97356 & $-0,68337$ \\
Lithuania & 2,77419 & $-2,06893$ & $-0,00925$ & $-0,54684$ & 0,15826 & 0,55816 & $-0,11512$ \\
Norway & $-0,51576$ & $-0,77084$ & 0,30816 & $-0,01135$ & 0,06309 & $-0,73448$ & 2,95228 \\
Portugal & 0,34540 & 0,43343 & $-0,08164$ & 0,46799 & 1,53993 & 0,76081 & 0,80110 \\
Slovakia & 1,14150 & 1,20419 & $-0,51914$ & $-0,81424$ & 0,93338 & $-2,08556$ & $-0,37348$ \\
Slovenia & 0,09310 & 1,49621 & 0,20962 & $-1,08697$ & 0,76776 & 2,33238 & 0,19618 \\
Spain & 0,18059 & 0,33922 & 0,05226 & 2,57163 & 0,32339 & $-0,59185$ & 0,56687 \\
Sweden & $-1,35319$ & $-0,45053$ & 0,33296 & $-0,91589$ & $-0,16946$ & $-0,59344$ & 0,11086 \\
\hline
\end{tabular}

It is interesting to see whether there is a relation between the different components and the balanced or theoretical rate of growth. As shown in Table 8, the Pearson's correlation coefficients for the different components and the balanced growth rate are not very high, although the first component is shown to be related. 
Table 8. Pearson's correlation between the principal components and the potential rate of growth.

\begin{tabular}{|ll|r|}
\hline Component 1 & Pearson's correlation & $-0,410$ \\
Component 2 & Sig. (bilateral) & 0,114 \\
& Pearson's correlation & $-0,020$ \\
Component 3 & Sig. (bilateral) & 0,943 \\
& Pearson's correlation & 0,313 \\
Component 4 & Sig. (bilateral) & 0,237 \\
& Pearson's correlation & 0,142 \\
Component 5 & Sig. (bilateral) & 0,599 \\
& Pearson's correlation & 0,106 \\
Component 6 & Sig. (bilateral) & 0,696 \\
& Pearson's correlation & $-0,170$ \\
Component 7 & Sig. (bilateral) & 0,529 \\
& Searson's correlation & 0,360 \\
& Sig. (bilateral) & 0,171 \\
\hline
\end{tabular}

There is, however, some correlation between the balanced growth rate and the shares of two sectors having high absolute factorial loads in the first component in the eigenvector. Both agriculture and real estate, renting and business services have high absolute factorial loads in the first component (Table 6) which is nearly significant in statistical terms, as shown in the table above. Table 9 displays the results. 
Table 9. Pearson's correlation between the share of sectors in eigenvector and the rate of balanced growth.

\begin{tabular}{|c|c|}
\hline Sector & $\begin{array}{c}\text { Pearson's } \\
\text { correlation } \\
\text { (Sig. bilateral) }\end{array}$ \\
\hline $\begin{array}{l}1 \text { Agriculture, hunting and forestry } \\
2 \text { Fishing } \\
3 \text { Mining and quarrying of energy producing materials } \\
4 \text { Mining and quarrying except energy producing materials } \\
5 \text { Manufacture of food products; beverages and tobacco } \\
6 \text { Manufacture of textiles and textile products } \\
7 \text { Manufacture of leather and leather products } \\
8 \text { Manufacture of wood and wood products } \\
9 \text { Manuf. of pulp, paper and paper products; publishing and printing } \\
10 \text { Manufacture of coke, refined petroleum products and nuclear fuel } \\
11 \text { Manufacture of chemicals, chemical products and man-made } \\
\text { fibres } \\
12 \text { Manufacture of rubber and plastic products } \\
13 \text { Manufacture of other non-metallic mineral products } \\
14 \text { Manufacture of basic metals and fabricated metal products } \\
15 \text { Manufacture of machinery and equipment n.e.c. } \\
16 \text { Manufacture of electrical and optical equipment } \\
17 \text { Manufacture of transport equipment } \\
18 \text { Manufacturing n.e.c. } \\
19 \text { Electricity, gas and water supply } \\
20 \text { Construction } \\
21 \text { Wholesale and retail trade; repair } \\
22 \text { Hotels and restaurants } \\
23 \text { Transport, storage and communication } \\
24 \text { Financial intermediation } \\
25 \text { Real estate, renting and business activities } \\
26 \text { Public administration and defence; compulsory social security } \\
27 \text { Education } \\
28 \text { Health and social work } \\
29 \text { Other community, social, personal service activities } \\
30 \text { Activities of households } \\
31 \text { Add_value \& consumption }\end{array}$ & $\begin{array}{r}-0,605(0,013)\left(^{*}\right) \\
0,268(0,315) \\
-0,182(0,500) \\
-0,412(0,113) \\
-0,382(0,144) \\
-0,323(0,223) \\
-0,218(0,417) \\
-0,084(0,758) \\
0,131(0,628) \\
0,178(0,509) \\
-0,303(0,254) \\
-0,487(0,055) \\
-0,272(0,308) \\
-0,035(0,898) \\
0,043(0,875) \\
-0,294(0,269) \\
0,395(0,130) \\
-0,356(0,176) \\
-0,238(0,374) \\
-0,239(0,372) \\
-0,273(0,305) \\
0,135(0,619) \\
0,192(0,475) \\
-0,163(0,546) \\
0,536(0,032)\left({ }^{*}\right) \\
0,125(0,644) \\
0,278(0,297) \\
0,419(0,106) \\
0,387(0,139) \\
0,210(0,435) \\
0,232(0,386)\end{array}$ \\
\hline
\end{tabular}

More exactly, for sector 1 (agriculture) the correlation is negative (Figure 3 ), since the higher the share of this sector in the eigenvector the lower the balanced growth rate. 
Figure 3. Share of Agriculture in the eigenvector and the balanced growth rate.

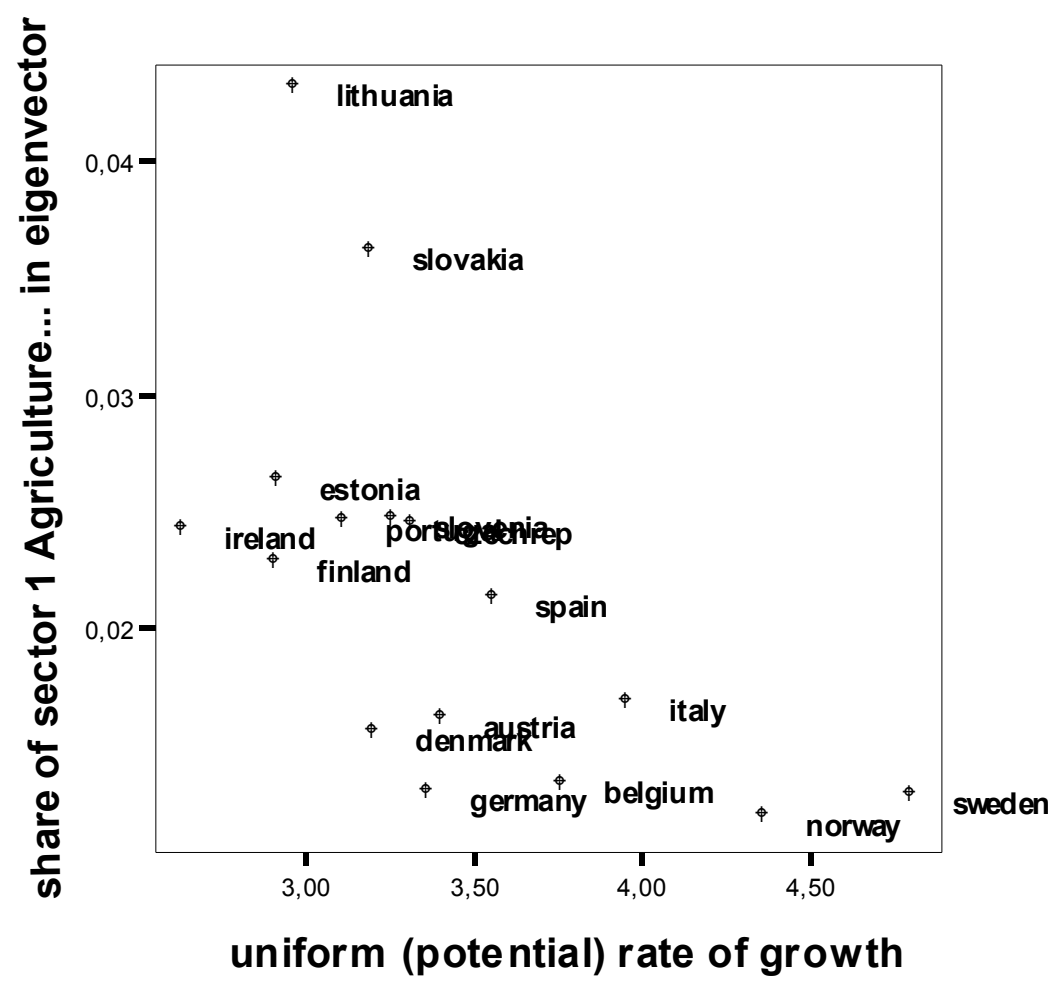

On the other hand, the correlation in the case of real estate, renting and business services is positive i.e. the higher share of this sector in the eigenvector, the higher the balanced growth rate (Figure 4). 
Figure 4. Share of sector 25 Real estate, Renting and Business Services in the eigenvector and the balanced growth rate.

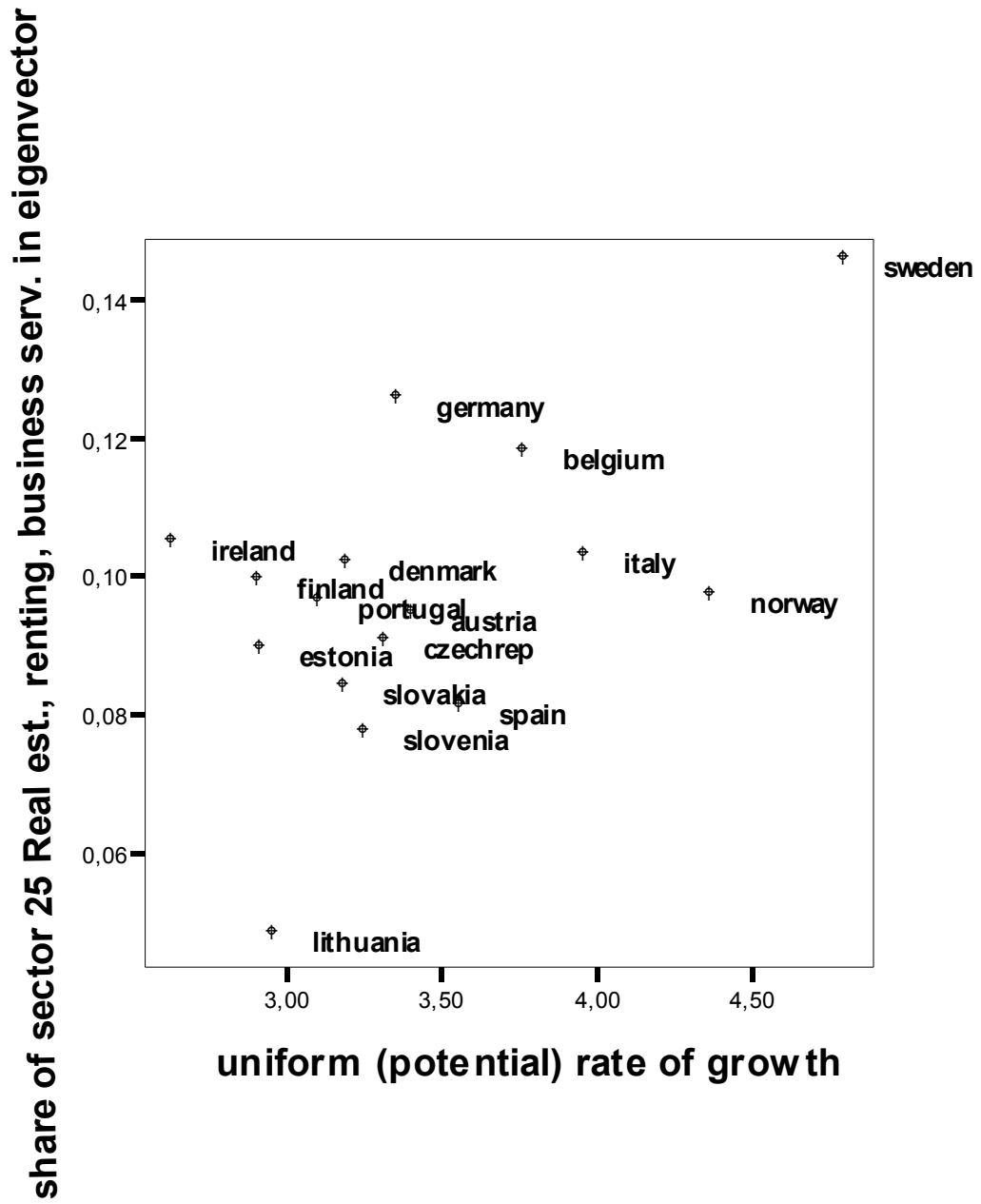

We have, therefore, computed the differences between the share of both sectors in the real output, and between the shares in the eigenvector, to see whether such differences and the differences between the actual and the uniform rates of growth are correlated. Results are shown in Table 10: 
Table 10. Relation between differences in shares and differences in rates of growth.

\begin{tabular}{|c|c|c|c|c|c|c|c|}
\hline \multirow[b]{2}{*}{ Country } & \multicolumn{3}{|c|}{$\begin{array}{c}\text { Sector 1: Agriculture, hunting and } \\
\text { forestry }\end{array}$} & \multicolumn{3}{|c|}{$\begin{array}{c}\text { Sector 25: Real estate, renting and } \\
\text { business activities }\end{array}$} & \multirow{2}{*}{$\begin{array}{c}\text { Difference } \\
\text { actual - uniform } \\
\text { growth } \\
\rho-g\end{array}$} \\
\hline & $\begin{array}{l}\text { share in } \\
\text { real output }\end{array}$ & $\begin{array}{l}\text { share in } \\
\text { eigenvector }\end{array}$ & difference & $\begin{array}{l}\text { share in } \\
\text { real output }\end{array}$ & $\begin{array}{l}\text { share in } \\
\text { eigenvector }\end{array}$ & difference & \\
\hline Austria & 0,0178 & 0,0159 & 0,0019 & 0,1427 & 0,0937 & 0,0490 & $-0,9865$ \\
\hline Belgium & 0,0139 & 0,0131 & 0,0007 & 0,1638 & 0,1174 & 0,0463 & $-1,5250$ \\
\hline Czech. R. & 0,0293 & 0,0242 & 0,0051 & 0,1113 & 0,0897 & 0,0216 & $-0,0509$ \\
\hline Denmark & 0,0241 & 0,0153 & 0,0088 & 0,1762 & 0,1013 & 0,0750 & $-1,1597$ \\
\hline Estonia & 0,0426 & 0,0261 & 0,0165 & 0,1176 & 0,0887 & 0,0290 & 4,5448 \\
\hline Finland & 0,0295 & 0,0226 & 0,0069 & 0,1258 & 0,0987 & 0,0272 & 0,6825 \\
\hline Germany & 0,0129 & 0,0127 & 0,0002 & 0,1797 & 0,1250 & 0,0547 & $-1,8113$ \\
\hline Ireland & 0,0288 & 0,0240 & 0,0049 & 0,1188 & 0,1043 & 0,0146 & 4,1572 \\
\hline Italy & 0,0195 & 0,0166 & 0,0029 & 0,1458 & 0,1023 & 0,0435 & $-2,5299$ \\
\hline Lithuania & 0,0502 & 0,0429 & 0,0073 & 0,0773 & 0,0475 & 0,0298 & 3,5997 \\
\hline Norway & 0,0117 & 0,0117 & 0,0000 & 0,1363 & 0,0966 & 0,0397 & $-1,8347$ \\
\hline Portugal & 0,0280 & 0,0244 & 0,0036 & 0,1237 & 0,0958 & 0,0279 & $-1,0891$ \\
\hline Slovakia & 0,0412 & 0,0360 & 0,0052 & 0,1023 & 0,0833 & 0,0190 & 1,7592 \\
\hline Slovenia & 0,0268 & 0,0244 & 0,0024 & 0,1082 & 0,0768 & 0,0314 & 1,0364 \\
\hline Spain & 0,0308 & 0,0210 & 0,0098 & 0,1264 & 0,0805 & 0,0458 & 0,2590 \\
\hline Sweden & 0,0156 & 0,0126 & 0,0030 & 0,2100 & 0,1449 & 0,0651 & $-1,5621$ \\
\hline & & correlation: & 0,65 & & correlation: & $-0,63$ & \\
\hline
\end{tabular}

There is evidence that over-representation in Agriculture widens the gap between the actual and the balanced rate of growth while overrepresentation in Real estate, renting and business services has the opposite effect. On the basis of these findings, we may conclude that countries with a large Agriculture sector are deemed to grow at a rate which is lower than the rate of balanced growth, while countries with a large Real estate, renting and business services sector tend to growth at a rate which is closer to the balanced one.

\section{Sensitivity Analysis.}

To identify the sectors that have the largest influence on the first eigenvector of matrix $(I-A)^{-1} B$, the rate of balanced growth in each country (and thus the indicator of efficiency which is independent from output composition), we look at the elasticity of that eigenvalue relative to 
the coefficients of the same matrix. Changes in the intermediate and capital input coefficients reflect the many disparate changes occurring in areas such as technical change, product composition and relative prices. As we distinguish intermediate from capital inputs, we must also consider two sets of elasticities, one for the $a_{i j}$ 's coefficients and one for the $b_{i j}$ 's coefficients. Overall efficiency depends on the amount of inputs that are used to produce one unit of final output in each sector of the economy, and also on the overall sector composition, but in this section we focus only on the coefficients. This analysis, therefore, completes the one we carried out earlier focused on sector composition.

A unit change in the intermediate input in $a_{i j}$ implies a change in the Leontief inverse, in the matrix $(I-A)^{-1} B$ and thus in the first eigenvalue, while a change in the $b_{i j}$ is directly mapped on to the first eigenvalue. It is the ensuing changes in the corresponding rate of balanced growth that we are interested in, since any reduction in the model's coefficients have a bearing on the efficiency of the system. The elasticity with regard to a single intermediate input coefficient $i$ and in sector $j$ in country $k$ (i.e. $a_{i j}^{k}$ or, simply, $a_{i j}$ ) and capital input coefficient $i$ in sector $j$ in country $k$ (i.e. $b_{i j}^{k}$ or $b_{i j}$ ) are defined, respectively, as: $\varepsilon_{i j}^{k a}=\frac{\Delta \rho}{\rho} / \frac{\Delta a_{i j}}{a_{i j}}$, and $\varepsilon_{i j}^{k b}=\frac{\Delta \rho}{\rho} / \frac{\Delta b_{i j}}{b_{i j}}$.

A high elasticity means that a small increase in the intermediate input coefficient $a_{i j}$ leads, ceteris paribus, to a greater increase in the eigenvalue i.e. to a larger reduction in efficiency. The differences in the elasticities are clearly greater across sectors than across countries. This means that there are specific sectors - and particular inputs in specific sectors - which in almost all countries are more important than others in respect to their influence on the first eigenvalue. Indeed, there are particular cells in the 
table that have distinctly high input coefficients and thus proportionally high elasticities. The average elasticity with respect to all the inputs coefficients in sector $j$ in country $k$ is defined as:

$\bar{\varepsilon}_{j}^{k a}=\sum_{i=1}^{N-1} \varepsilon_{i j}^{k a} /(N-1)$.

Table 11 reports the ratios between those averages and the country average. The sectors whose input coefficients exercise the largest influence across all countries are: sector 29 (Construction), sector 25 (Real estate, renting and business activities), sector 21 (Trade), sector 23 (Transport and Communication), and sector 5 (Manufacture of foods). For particular sectors in specific countries, we observe the strong influence of sector 11 (Chemicals industry) in Lithuania, sector 16 (Manufacture of electrical and optical equipment) in Estonia, sector 19 (Electricity, gas and water supply) in Slovakia, and sector 14 (Financial intermediation) in Austria. 
Table 11. Relative of the eigenvector with respect to elasticities of input coefficients (national average $=100$ )

\begin{tabular}{|c|c|c|c|c|c|c|c|c|c|c|c|c|c|c|c|c|c|}
\hline & Sectors & Austria & Belgium & $\begin{array}{l}\text { Czech } \\
\text { R. }\end{array}$ & Denmark & Estonia & Finland & Germany & Ireland & Italy & Lithuania & Norway & Portugal & Slovakia & Slovenia & Spain & Sweden \\
\hline 1 & Agriculture... & 70,97 & 52,76 & 84,36 & 87,29 & 99,03 & 100,58 & 57,50 & 103,83 & 50,09 & 173,55 & 46,86 & 78,10 & 136,79 & 82,60 & 68,53 & 45,03 \\
\hline 2 & Fishing & 0,60 & 2,21 & 0,38 & 4,97 & 7,52 & 1,97 & 0,59 & 2,14 & 2,02 & 2,90 & 24,53 & 3,05 & 0,31 & 0,84 & 5,81 & 1,18 \\
\hline 3 & Mining (energy prod.) & 37,34 & 42,77 & 64,33 & 4,12 & 43,79 & 45,44 & 62,64 & 0,00 & 17,16 & 148,77 & 11,86 & 236,11 & 82,63 & 31,51 & 39,76 & 44,52 \\
\hline 4 & $\begin{array}{l}\text { Mining (except energy } \\
\text { prods.) }\end{array}$ & 11,01 & 17,60 & 10,44 & 6,20 & 4,90 & 25,89 & 8,75 & 48,47 & 9,26 & 19,16 & 11,22 & 7,41 & 15,41 & 14,15 & 11,81 & 12,21 \\
\hline 5 & Manuf. of food... & 159,94 & 201,70 & 217,17 & 175,27 & 215,15 & 197,85 & 189,25 & 280,37 & 215,99 & 365,40 & 241,89 & 244,47 & 212,09 & 207,75 & 276,09 & 169,74 \\
\hline 6 & Manuf. of textiles. & 67,62 & 58,94 & 56,33 & 51,59 & 75,13 & 36,77 & 61,74 & 62,76 & 98,04 & 74,68 & 40,63 & 81,87 & 46,87 & 122,15 & 73,85 & 35,75 \\
\hline 7 & Manuf. of leather.. & 14,48 & 7,89 & 15,41 & 9,07 & 20,42 & 7,11 & 13,30 & 13,03 & 36,52 & 22,45 & 9,09 & 14,05 & 13,15 & 23,28 & 19,93 & 7,25 \\
\hline 8 & Manuf. of wood. & 37,39 & 23,78 & 28,98 & 36,10 & 31,81 & 45,41 & 26,15 & 32,62 & 27,82 & 49,57 & 43,46 & 30,00 & 24,73 & 21,05 & 37,54 & 41,54 \\
\hline 9 & Manuf. of pulp, & 9465 & 76,79 & 71,64 & 9754 & 7,88 & 114,76 & 82,76 & 62,98 & 82,04 & 69,18 & 89,59 & 73,65 & 58,61 & 92,57 & 80,22 & 90,86 \\
\hline 10 & $\begin{array}{l}\text { Manuf. of coke, refined } \\
\text { petr... }\end{array}$ & 54,65 & 102,78 & 90,76 & 48,31 & 70,37 & 69,85 & 70,23 & 0,00 & 71,36 & 0,00 & 64,39 & 85,73 & 64,23 & 107,52 & 93,39 & 61,00 \\
\hline 11 & Manuf. of chemicals... & 111,59 & 160,80 & 135,90 & 74,61 & 159,90 & 99,18 & 115,39 & 72,52 & 138,58 & 283,79 & 88,63 & 139,00 & 135,26 & 149,26 & 150,63 & 71,16 \\
\hline 12 & $\begin{array}{l}\text { of rubber and } \\
\ldots\end{array}$ & 6,83 & 6 &, 77 & 2 &, 57 & 0 & 8 &, 02 & , 39 & 8 & 59 & 52 & 49,76 & 78 & 42,80 & 1,55 \\
\hline 13 & $\begin{array}{l}\text { Manuf. non-metallic min. } \\
\text { prod. }\end{array}$ & 41,17 & 42,79 & 53,96 & 40,16 & 32,75 & 36,76 & 48,19 & 22,31 & 54,94 & 59,48 & 31,21 & 58,45 & 51,00 & 52,98 & 58,36 & 25,23 \\
\hline 14 & Manuf. metal prods. & 117,07 & 139,64 & 169,01 & 98,05 & 162,58 & 138,64 & 114,94 & 58,07 & 145,78 & 86,46 & 111,51 & 107,85 & 171,00 & 207,38 & 154,36 & 127,27 \\
\hline 15 & $\begin{array}{l}\text { Manuf. of machinery } \\
\text { n.e.c. }\end{array}$ & 81,68 & 59,07 & 88,84 & 69,86 & 62,48 & 106,64 & 75,31 & 39,63 & 76,03 & 55,50 & 77,35 & 94,73 & 112,60 & 78,12 & 63,08 & 80,76 \\
\hline 16 & Manuf. Electrical.. & 97,06 & 98,06 & 169,63 & 105,67 & 459,69 & 150,95 & 119,11 & 158,91 & 86,67 & 72,26 & 102,64 & 83,74 & 95,32 & 98,08 & 91,13 & 144,25 \\
\hline 17 & Manuf. transport equip. & 90,85 & 137,16 & 81,80 & 50,89 & 38,33 & 52,56 & 144,14 & 106,34 & 96,99 & 56,76 & 115,08 & 119,37 & 95,98 & 145,57 & 141,57 & 132,18 \\
\hline 18 & Manufacturing n.e.c. & 44,51 & 38,43 & 36,78 & 32,73 & 27,42 & 28,48 & 38,48 & 95,29 & 46,53 & 52,99 & 37,92 & 39,03 & 31,39 & 23,86 & 47,38 & 36,05 \\
\hline 19 & Electricity. & 90,68 & 54,05 & 178,66 & 46,22 & 120,55 & 49,98 & 52,94 & 54,99 & 77,44 & 116,06 & 26,37 & 89,97 & 292,28 & 59,66 & 81,35 & 40,69 \\
\hline 20 & tin & 279,16 & 368,25 & 408,35 & 394,79 & 194,10 & 365,55 & 322,26 & 320,82 & 285,48 & 272,76 & 343,19 & 398,05 & 386,63 & 417,80 & 397,74 & 191,10 \\
\hline 21 & $\begin{array}{l}\text { Wholesale and retail } \\
\text { trade... }\end{array}$ & 255,39 & 288,76 & 142,72 & 262,97 & 206,52 & 293,56 & 225,23 & 170,09 & 376,26 & 224,33 & 237,35 & 249,01 & 187,40 & 256,45 & 187,39 & 183,01 \\
\hline 22 & Hotels and restaurant & 106,29 & 70,70 & 42,62 & 66,08 & 52,91 & 77,84 & 66,39 & 130,25 & 117,21 & 30,37 & 103,50 & 107,90 & 51,96 & 73,18 & 142,09 & 61,54 \\
\hline 23 & $\begin{array}{l}\text { Transport, } \\
\text { communication }\end{array}$ & 224,35 & 240,32 & 196,70 & 369,34 & 297,70 & 183,97 & 213,45 & 257,68 & 242,63 & 228,92 & 383,34 & 111,21 & 208,48 & 173,74 & 212,32 & 276,40 \\
\hline 24 & Financial interm & 282,23 & 80,86 & 91,43 & 107,30 & 47,05 & 55,68 & 184,67 & 163,47 & 87,32 & 16,57 & 32,99 & 29,12 & 56,19 & 30,83 & 70,06 & 67,74 \\
\hline 25 & $\begin{array}{l}\text { Real estate, renting, } \\
\text { business }\end{array}$ & 283,74 & 353,40 & 298,89 & 337,13 & 202,93 & 322,82 & 347,43 & 369,01 & 274,51 & 120,02 & 341,96 & 278,31 & 242,64 & 221,30 & 236,79 & 580,27 \\
\hline 26 & Public administration.. & 94,29 & 46,91 & 55,59 & 107,28 & 85,66 & 116,35 & 82,00 & 122,81 & 60,82 & 110,83 & 141,16 & 32,62 & 72,74 & 91,52 & 46,14 & 134,75 \\
\hline 27 & Education & 21,83 & 18,37 & 21,69 & 59,73 & 38,50 & 59,22 & 31,23 & 39,07 & 26,07 & 31,47 & 48,97 & 28,87 & 12,31 & 30,82 & 20,30 & 79,23 \\
\hline 28 & Health and social work & 102,04 & 95,42 & 41,86 & 115,54 & 39,75 & 93,27 & 100,12 & 132,41 & 67,32 & 55,95 & 89,53 & 73,35 & 37,48 & 62,50 & 65,88 & 126,86 \\
\hline 29 & Other services... & 90,59 & 79,24 & 78,99 & 105,96 & 59,63 & 86,97 & 102,01 & 40,11 & 81,74 & 74,13 & 77,18 & 60,50 & 54,79 & 66,72 & 83,68 & 100,91 \\
\hline 30 & Activities of households & 0,00 & 0,00 & 0,00 & 0,00 & 0,00 & 0,00 & 0,00 & 0,02 & 0,00 & 0,00 & 0,00 & 0,00 & 0,00 & 0,00 & 0,00 & 0,00 \\
\hline & Average & 100,00 & 100,00 & 100,00 & 100,00 & 100,00 & 100,00 & 100,00 & 100,00 & 100,00 & 100,00 & 100,00 & 100,00 & 100,00 & 100,00 & 100,00 & 100,00 \\
\hline
\end{tabular}


To make cross country comparisons in the above mentioned five sectors $(29,25,21,23$ and 5), Table 12 shows for specific sectors the ratio between each country's average elasticities and the overall average. Through this means, we find that even though in general the ratios are rather similar across countries, there are nevertheless some countries which have higher average elasticities in sensitive secors and are thus less efficient than others in those sectors. See, for example, the cases of Estonia in sector 23 (Transport) and Sweden in sector 25 (Real Estate) (See Table 12).

Table 12. Relative elasticities of the most important input coefficients.

\begin{tabular}{|c|c|c|c|c|c|}
\hline Sectors & $\begin{array}{c}5 \\
\text { Manufacture } \\
\text { of food } \\
\text { products; } \\
\text { beverages } \\
\text { and tobacco }\end{array}$ & Construction & $\begin{array}{c}21 \\
\text { Wholesale } \\
\text { and retail } \\
\text { trade; repair } \\
\text { of motor } \\
\text { vehicles, } \\
\text { motorcyc., } \\
\text { personal and } \\
\text { household } \\
\text { goods }\end{array}$ & $\begin{array}{c}\text { Transport, } \\
\text { storage and } \\
\text { communicati } \\
\text { on }\end{array}$ & $\begin{array}{l}\text { Real estate, } \\
\text { renting and } \\
\text { business } \\
\text { activities }\end{array}$ \\
\hline Austria & 59,23 & 71,35 & 92,28 & 77,17 & 78,87 \\
\hline Belgium & 98,79 & 124,50 & 138,00 & 109,34 & 129,95 \\
\hline Czech. Rep & 102,82 & 133,44 & 65,93 & 86,50 & 106,23 \\
\hline Denmark & 56,55 & 87,91 & 82,78 & 110,69 & 81,65 \\
\hline Estonia & 168,10 & 104,67 & 157,44 & 216,06 & 119,03 \\
\hline Finland & 73,57 & 93,82 & 106,51 & 63,54 & 90,11 \\
\hline Germany & 65,63 & 77,13 & 76,21 & 68,76 & 90,45 \\
\hline Ireland & 158,61 & 125,27 & 93,89 & 135,41 & 156,71 \\
\hline Italy & 91,78 & 83,73 & 156,01 & 95,77 & 87,57 \\
\hline Lithuania & 151,22 & 77,91 & 90,59 & 88,01 & 37,29 \\
\hline Norway & 108,13 & 105,88 & 103,52 & 159,18 & 114,75 \\
\hline Portugal & 100,14 & 112,53 & 99,52 & 42,32 & 85,58 \\
\hline Slovakia & 81,75 & 102,85 & 70,48 & 74,64 & 70,21 \\
\hline Slovenia & 87,60 & 121,60 & 105,51 & 68,05 & 70,05 \\
\hline Spain & 115,31 & 114,65 & 76,36 & 82,37 & 74,24 \\
\hline Sweden & 80,78 & 62,77 & 84,98 & 122,18 & 207,30 \\
\hline Average & 100,00 & 100,00 & 100,00 & 100,00 & 100,00 \\
\hline
\end{tabular}

A capital coefficient can be decomposed into three factors according to equation (7) $b_{i j}=t_{i j} e_{i} c_{j}$, i.e. the service life, the fraction of total fixed investment supplied by the origin sector $i$, and the amount of replacement investment in the destination sector $j$. A unit change in any one of these factors implies a change in the matrix $B$ and thus in the corresponding first eigenvalue of matrix $(I-A)^{-1} B$. In particular, a unit change in the 
coefficient regarding the capital input in the destination sector, i.e. $\Delta c_{j}=1$, implies a change in the capital coefficient concerning the specific origin sector equal to $\Delta b_{i j}=t_{i j} e_{i}$. This change feeds upon the first eigenvector through the matrix $(I-A)^{-1} B$, and the elasticity of the corresponding first eigenvector with respect to this capital coefficient is precisely what interests us. Table 13 shows that differences among sectors are quite large, and thus that differences in the sector composition matter a great deal when included are sectors where the elasticity is high, such as Agriculture (sector 1) and Real estate (sector 25) among others. 
Table 13. Relative elasticies of the eigenvector with respect to replacement investment (national average $=100)$.

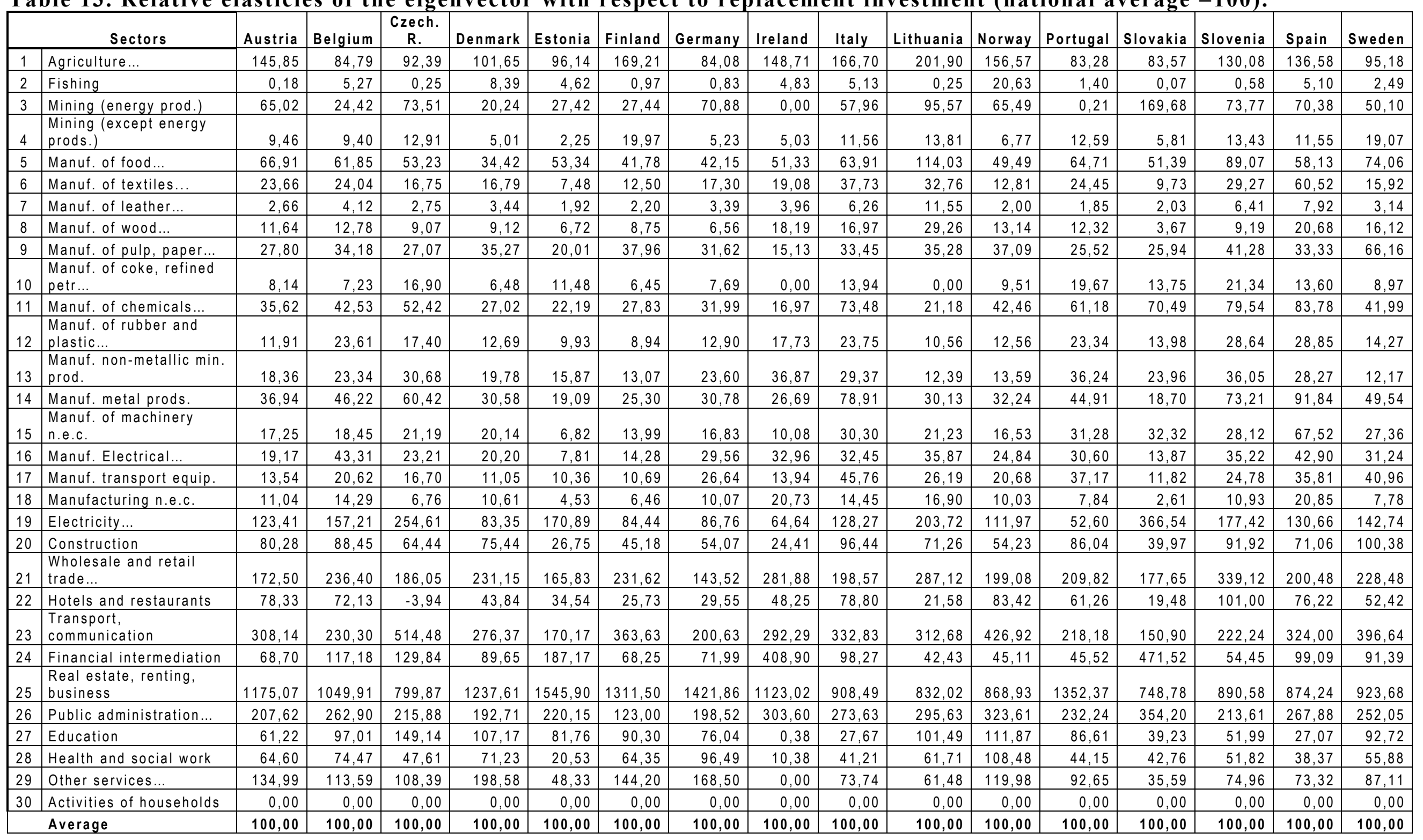




\section{Conclusions.}

By utilizing the EUROSTAT input-output data base, and Italian data on service life of capital assets, we have built a dynamic input-output model for 16 European countries. The model has been used to compute the various rates of balanced growth in the countries concerned as a starting point for analysis of national differences in productive efficiency. The assumption, indeed, has been that high productive efficiency raises total factor productivity and thus the rate of balanced growth. The actual growth rate is in our sample for the most part different from the balanced rate, and this may reflect differences between the output composition actually observed and the particular one which would be required to produce the balanced growth path. Principal component analysis of the output structure shows that two dominant components account for more than $46 \%$ of total variance in the national rates of aggregate actual growth, and there are a few sectors the presence of which - having higher absolute factorial loads in the first two components - seem to be more highly correlated with the rate of balanced growth. Among these, Agriculture and Real Estate, renting and business activities are found to be critical to growth performance in that a higher share in the economy of Agriculture is negatively associated with the rate of balanced growth and, respectively, a higher share of Real Estate, renting and business activities is positively associated. In particular, overrepresentation of Agriculture is associated with a larger gap between the actual and the balanced rates of growth, while overrepresentation of Real estate etc. is associated with a narrow gap between the two rates.

By computing the sensitivity of the rate of balanced growth to the levels of intermediate input coefficients and capital coefficients, we found that differences amongst sectors are larger than those amongst countries. In particular, we found that there are some sectors, notably Agriculture and Real Estate, in which intermediate and capital coefficients are critical to the rate of aggregate growth because the elasticity of the rate of balanced 
growth with respect to the coefficients is particularly high. To put it differently, a unit change in the coefficients in the two sectors exerts the highest impact on the balanced rate of growth. Thus a completely different exercise yields results which are convergent with those obtained from the principal component analysis. The broad conclusion that can be drawn from our investigation is that even though the sixteen European countries are rather similar from the point of view of their input-output structures, there are some countries that are less efficient, and some others that are more so, in the sectors we have called the sensitive sectors i.e. those whose size matters in establishing the gap between the actual rate of growth and the rate of balanced growth. The obvious conclusion is that overrepresentation in growth-enhancing sectors is a favourable condition while overrepresentation in growth-reducing sectors is unfavourable. From a policy point of view, it might be argued that countries which are overrepresented and inefficient in growth-reducing sectors could gain a great deal from reducing that overrepresentation or by increasing efficiency in those sectors. 


\section{Appendix.}

To focus more closely on how a change in the model's coefficients hing on the growth rate, we express the uniform growth rate $\lambda$ in terms of both the model's value and technical coefficients. The closed dynamic model for such an economy $(I-A-\lambda B) x=0$ requires that $|I-A-\lambda B|=0$, which in the simple case for two sectors only, and in expanded form reads:

$\left|\begin{array}{cc}1-a_{11}-\lambda b_{11} & -a_{12}-\lambda b_{12} \\ -a_{21}-\lambda b_{21} & 1-a_{22}-\lambda b_{22}\end{array}\right|=0$

To further simplify matters, we assume that there is minimal interaction, i.e. $a_{11}=a_{22}=0$, and that the second sector does not produce capital goods, i.e. $b_{21}=b_{12}=0$, thus solving, the resulting equation: $\left|\begin{array}{cc}1-\lambda b_{11} & -a_{12}-\lambda b_{12} \\ -a_{21} & 1\end{array}\right|=0$, or: $\left(1-\lambda b_{11}\right)-a_{21}\left(a_{12}+\lambda b_{12}\right)=0$, one gets: $\lambda=\frac{1-a_{12} a_{21}}{b_{11}+a_{12} b_{21}}$. The expressions shows that the lower the $a_{i j}$ 's and the $b_{i j}$ 's, the higher the balanced growth rate; indeed, the latter increases when the amount of resources left after deduction for intermediate consumption, i.e. $\left(1-a_{12} a_{21}\right)$, increases and the amount of resources needed for making investments, i.e. $\left(b_{11}+a_{12} b_{21}\right)$, decreases.

All coefficients in the model are intended to be value coefficients as they include relative prices computed over costs, factor rents included, it is then interesting to see whether changes in prices affect the growth rate. This can be done by considering the expansion of value coefficients into quantity or technical coefficients $\left(\alpha_{i j}\right)$ and prices $\left(p_{i}\right)$ :

$$
\lambda=\frac{1-a_{12} a_{21}}{b_{11}+a_{12} b_{21}}=\frac{1-\frac{p_{1}}{p_{2}} \alpha_{12} \frac{p_{2}}{p_{1}} \alpha_{21}}{\frac{p_{1}}{p_{1}} \beta_{11}+\frac{p_{1}}{p_{2}} \alpha_{12} \frac{p_{2}}{p_{1}} \beta_{21}}=\frac{1-\alpha_{12} \alpha_{21}}{\beta_{11}+\alpha_{12} \beta_{21}}
$$


The expression shows that changes in rents, and thus prices, do not alter the aggregate rate of growth and the corresponding aggregate rate of profit in the economy since the rate $\lambda$ depends on the $\alpha_{i j}$ 's and the $\beta_{i j}$ 's only. In the two sectors case, therefore, relative prices are irrelevant. 


\section{Citations.}

Brody, A. (1997) "The Second Eigenvalue of the Leontief Matrix", Economic Systems Research, 9 (3): 253-258.

ISTAT (2002) "Gli investimenti fissi di Contabilità Nazionale dopo la revisione: Nota metodologica", Metodi e Norme, 14, Roma.

ISTAT (2002) "Principali innovazioni della revisione della serie degli investimenti fissi per branca proprietaria, della stock di capitale e degli ammortamenti (Nota metodologica)", www.istat.it .

Leontief, W. (1951) The Structure of the American Economy, Oxford University Press, New York.

Martellato, D and Miguel-Angel Tarancon Moran (2005) "Openess, Dependency and productive Efficiency, in Nine European Countries”, Nota di Lavoro 2005.09, Università Ca' Foscari, Dipartimento di Scienze Economiche, Venezia.

Ten Raa, T. (2005) The Economics of Input-Output Analysis, Cambridge University Press, New York.

UNECE (2004) "Survey of National practices in Estimating Service Lives of Capital Assets", Joint UNECE, Eurostat, OECD Meeting on National Accounts, Geneva, 28-30 April 2004.

Wolff, E.N. (1985) "Industrial Composition, Interindustry Effects, and the U.S. Productivity Slowdown", Review of Economics and Statistics, 67 (2): 268-277. 